\title{
DEVLETLERİN ANAYASASI VE AVRUPA BİRLİĞİ ANAYASASI*
}

\author{
Herbert SCHAMBECK ${ }^{* *}$ \\ Çeviri: Günay Develi
}

Anayasa, bir durumun, bir halin ifadesidir. Böyle bir durum kendini bir insanın duruşunda gösterebilir. $\mathrm{O}$ zaman söz konusu insan için 'şu ya da bu durumda bulunuyor' denilir, böylece o kişinin halinin sabit olduğu belirtilir. Aynı söyleyişi bireysel çerçeveyi aşarak toplumsal olgular için de - yani devletlerin ve de onların toplumlarının anayasaları için - kullanmak olasidir.

İster bireysel ister toplumsal ölçekte görülsün, anayasa kavramı hep bir düzen beklentisini içerir. Bu beklentinin yerine getirilip getirilmemesine göre ise bireyin veya toplumun iyi ya da kötü bir durumda olduğu yargısına varilır.

Konu edilen düzenin koşulları, dolayısıyla ilgili anayasanın oluşmasını sağlayan koşullar insanlara, devletlere ve onların uluslararası düzendeki birliklerine göre farklılık gösterir.

Her devletin anayasasının kendisi halkların oluşturduğu birlik için de, birey için de kader belirleyici olacak kadar önceliklidir. İnsan, ARISSTOTELES'in artık neredeyse klasikleşmiş kavramıla dile getirdiği gibi, bir zoon politikondur'; yani insan, kişilik gelişimine toplumla ilinti içinde başlayan ve onu toplumsal Sen ile bulan bir varlıktır.

9 Mayıs 2004 Avrupa Günü münasebetiyle Marmara Üniversitesi Avrupa Topluluğu Enstitüsü'nün düzenlediği toplantıda sunulan bildiri.

Prof. Dr., Avusturya Federal Konseyi Eski Başkanı 


\section{Demokratik Anayasal Devlet}

Toplumsallığın en gelişmiş biçimi devlettir. Devlet, bireyin ve toplumun üstünde bulunan bir iktidar birliğidir ve tek olma koşulu ile üstün işlevini görür. Bu üstün işlev kendini devlet gücünün kullanımında gösterir. Romalıların hukuk anlayışında bu, Latince "imperium" kavramı ile anlatılırdi. ${ }^{3}$

Kamusal ve özel yaşamı şekillendiren $\ddot{u} c ̧$ alan vardır: Bireyin kişisel isteklerini de içeren özel alan, toplumun çıkarlarını temsil eden dernekleri ile birlikte toplumsal alan ve devletin emperyal yönü ile ereklerine - ki günümüzde bu erekler çok yönlüdür ve hukuk ile iktidar ereklerini olduğu kadar kültür ve refah ereklerini de kapsar - hizmet eden devlet alanı. ${ }^{4}$

Insanların istekleri, toplumun organize çkarlan ve devletin erekleri günümüzde olanaklar ölçüsünde hem huzur ve düzen ile güvenliğin sağlanmasına, hem kültürel gelişme, ekonomik büyüme ve toplumsal güvenliğin korunmasına yöneliktir.

Ancak bu kültürel, ekonomik ve sosyal devletin görevlerini hukuk devleti ${ }^{5}$ olarak yerine getirmesi şart koşulur, yani onun eylemleri yasalara bağlı kalmalı, böylece birey için öngörülebilir ve kestirilebilir olmalıdır. Devletin bu şekilde çok amaçlı olarak işletilmesinin ve demokratik hukuk devletinin yasalara bağlı kalması gerekliliğinin sonucunda baş döndürecek kadar artan yasalar sayısı devletin bireyleri için sadece hukuka güveni değil, ne yazık ki sıklıkla bilgisizlik nedeniyle hukuka güvensizliği de beraberinde getirmiştir.

Kurallardır devletin düzenini ve dolayısıyla onun anayasasını temellendiren. Onlar için ARİSTOTELES "politeia", daha sonra CICERO "constitutio"" ve "status rei publicae" kavramlarını kullanmıştır.

Yüzyılları kapsayan tarihleri içinde bu kurallar dizgesi önce antik çağda felsefi veya teokratik yaklaşımlara göre, sonraki dönemlerde, özellikle monarşilerde, ise hükümdarlar ile yapılan anlaşmalara göre şekillenirdi. Söz konusu anlaşmalar yeniçağ akılcılığının getirdiği akılcı iyimserliğin, ayrıca demokrasi ile liberalizmin karşılıklı etkileşiminin etkisiyle günümüzde egemen olan anayasal kanunlara dönüştü. 
Anayasanın anlaşma şekli zamanla yerini kanun şekline bırakmıştı. Artık toplumsal sınıflar temsilcileri aracılığıyla baştaki hükümdarla bir tür anayasa sözleşmesi üzerinde uzlaşmıyor, onun yerine halkın kendi seçtiği temsilciler aracılığıyla halka bir anayasa kanununu sunuluyor ve yerine göre halkoylamasına tabi tutuluyordu. ${ }^{10}$

Demokratik anayasa devleti ${ }^{I I}$ anlayışına ulaşan bu gelişmeyi özellikle kuzey Amerika kolonilerinin tarihinde ve burada yaşayan müstemlekecilerle İngiliz sarayı arasında yapılan toprak ekimi anlaşmalarında görmek olasıdır. $^{12}$ Örnek olarak bu sözleşmelerin en eskisi olan ve New Plymouth'un kurulmasından önce 11 Kasım 1620 tarihinde daha Mayflower gemisinde ilk göçmenler sayılan Pilgrimfathers arasında yapılan anlaşma anılabilir. ${ }^{13}$ Söz konusu anlaşmalar, daha sonra 11 Eylül $1787^{\prime} \mathrm{de}^{14}$ Amerika Birleşik Devletleri'nin kuruluş aşamasında imzalanan anayasa gibi, anayasaların en eski örnekleri sayılırlar ve iki öbeğe ayrılmış durumdadırlar: İlki Bill or Decleration of rights başlığını taşır ve bir tür temel haklar katalogudur, diğeri Plan or Frame of Government ismiyle devlet teşkilatını konu edinir. $\mathrm{Bu}$ ikinci öbek devlet otoritesinin üç temel işlevde, yani yasama, yürütme ile yarg1 ve güçler ayrilığı ilkesinin kullanımını düzenlemekteydi. ${ }^{15}$

Güçler ayrılığı ${ }^{16}$ ilkesi kendi düşünce tarihi boyunca $\operatorname{HESIOD}^{17}$, POLYBIOS $^{18}$, ARITOTELES ${ }^{19}$, HOBBES $^{20}$ ve MONTESQUIEU $^{21}$ tarafından klasikleştirilmiş ve devletin üç ana işlevinin karşılıklı olarak birbirini denetlemesi şeklinde tanımlanmıştı. Ancak günümüzün parlamenter yönetim sisteminde bu denetim görevi biraz zayıflamış durumdadır ve meclis nadiren hükümeti denetler, çünkü artık parlamenter çoğunluğun kendisi hükümeti oluşturmaktadır. ${ }^{22}$ Günümüzde balance of power, yani güç dengesi anlamındaki güç ayrılığı daha ziyade hükümet partileri ile muhalefet, partiler ile kitle iletişim araçlan, parlamenter devlet iradesi ile halkoylaması ya da halkın eğilimin saptanması gibi anayasal uygulamalar arasında sağlanmaktadır. Federal devletlerde bu denge federal yönetim ile eyaletler, kamusal yaşamda ise siyasi partiler ile sivil kuruluşlar, ayrıca politikacılar ile devlet memurları arasında kurulmaktadır. ${ }^{23}$

Bu politik gerçeklik devletlerin anayasaları tarafından desteklenmektedir. Anayasaların ilgili göstergeleri ise şunlardır: .Öörneğin Almanya'da Bonner Grundgestz Deutschlands ${ }^{24}$ ismi ile yapıldı $\breve{g}_{1}$ gibi bir anayasa kanunu; ya da değişik anayasa hukuku kaynakları ${ }^{25}$, sözgelimi Avusturya'dakiler ${ }^{26}$; demokratik bir seçme hakkı, daha açık bir deyişle oy hakkı olan kadın ve 
erkekler için genel, özgür ve dolaysız bir seçme hakkı; temel haklar; parlamenter devlet iradesi; devletin eylemlerinin anayasaya ve yasalara uygunluğu; mahkemelerin bağımsızlığı, yönetim birimlerinin bir dizge bağlamında üst - ast ilişkileri içinde oluşu ve yasalarca denetlenebilmesi; anayasal hukuk düzeni içinde hak arama yollannın açık oluşu; hesapların ve eylemlerin denetime tabi olması; nihayet resmi görev yapanların objektif sorumluluk taşıması.

Demokratik devletlerin anayasalarının bu göstergeleri ${ }^{27}$ bir devletin halkının hukuk, anayasa ve demokrasi bilincinin genelde uzun süren bir gelişme evresi sonucunda ortaya çıkmıştır. Onlar ayrıca devlet ile toplumun, devlet ile dinin, ama aynı zamanda siyaset ile silahlı güçlerin ayrı olmasından da ileri gelirler. Ancak bu ayrilık zitlık anlamına gelmez, aksine, sadece bir farklılığı dile getirir ve kurumlanı farklılıklanı ile birlikte aralarında karşılıklı bir ilinti oluşturmaları gerektiğini, birbirlerini tamamlayarak sonuçta - tüm anayasal kurumlarda olduğu gibi - kendileri için değil, insana hizmet için var olduklarını anlatır. Anayasanın sayılan göstergeleri bir devletin insanlanının sorumluluk bilincinin düzgüsel ifadesidir ve bir devletin anayasa hukukunun aslında yazılı bir siyaset olduğunu gösterir.

\section{Avrupa Devletlerinin Anayasalarının Gelişmesi Üzerine}

Avrupa devletlerinin anayasaları incelendiğinde ${ }^{28}$ onların değişik zamanlarda farklı geleneklerden doğduğu görülür ${ }^{29}$. Artık sadece Lüksemburg'un anayasası 19. yüzyıla dayanır, daha doğrusu 1868 yılında meydana getirilmiş ve son olarak 1999 yılında değiştirilmiştir. ${ }^{30}$

Avusturya'da cumhuriyetin 1918'de ilan edilmesinin ardindan devlet teşkilatının yapısı 1920 yılında benimsenen Federal Anayasa Kanunu ("Bundes-Verfassungsgesetz") ${ }^{31}$ ile düzenlenmiştir ve bu kanunun taslağ 1 HANS KELSEN'e dayanır ${ }^{32}$. Temel haklar ${ }^{33}$ ise, ki onlara 1950'de Avrupa insan haklan konvansiyonu ${ }^{34}$ ile eklenenler ve Avusturya'da 1964 yilından beri yasalarda ifade bulanlar $^{35}$ da dahildir, 1867 yılından kalma Vatandaşların Genel Haklarını İçeren Aralık Anayasası'nda yazılıdır ("Staatsgrundgesetz über die allgemeinen Rechte der Staatsbürger der Dezemberverfassung 1867 "). ${ }^{36}$ Yani temel haklar ile ilgili düzenlemeler KAYSER FRANZ JOSEF zamanından kalmadır. Burada monarşi ile cumhuriyet gibi farklı devlet şekilleri tek bir anayasal düzeninin geleneğinde yer bulmaktadır. 
Danimarka $(1953)^{37}$, İsveç $(1975)^{38}$ ve Hollanda $(1983)^{39}$ anayasalarında olduğu gibi daha eski metinlere dayanan bazı Avrupa anayasalarına, sonradan kısmen değiştirilmiş olsalar da, bugün bile 19. yüzyılın gölgesi düşmektedir.

Avrupa' $\mathrm{da}^{40}$ İkinci Dünya Savaşı gibi otoriter dönemlerin ardından meydana getirilen anayasalar kendi içlerinde bir grup oluştururlar. IV. Fransa Cumhuriyeti'nin anayasası (1946) ${ }^{41}$, İtalya'nınki $(1948)^{42}$ ve Bonner Grundgesetz adiyla Bonn kentinde kabul edilen Alman anayasası (1949) ${ }^{43}$ bu grupta sayılır. Berlin duvarının 1989 yılında yıkılması, Doğu Almanya Cumhuriyeti'nin varlığının sona ermesi ve iki Almanya'nın birleşmesiyle Alman anayasası birliğe yeni katılan orta ve doğu Almanya'daki ${ }^{44}$ eski eyaletlere de yayıldı. Hatta bu anayasa yetmişli yıllarda diktatörlük rejiminin üstesinden gelmek durumunda olan birçok devletin anayasası için sağlam bir örnek teşkil etmişti, sözgelimi 1975 'te Yunanistan ${ }^{45}$, 1976'da Portekiz $^{46}$ ve $1978^{\prime}$ de İspanya ${ }^{47}$ için.

Demokratik anayasal devlet düzeni yönünde kaydedilen bu aşamaların dışında kalan anayasalar da vardır. Bağımsız bir devlet kurma çabasından doğan İrlanda anayasası ${ }^{48}$ (1937) ve yönetim sistemini iyileştirmeyi amaçlayan V. Fransa cumhuriyeti anayasası ${ }^{49}$ (1958) bunlardandır.

Anılan bu demokratik anayasal devlet modellerinden başka orta ve doğu Avrupa'da İkinci Dünya Savaşı'ndan sonra Sovyetlerin baskısıyla, dolayısıyla Marxizmin etkisiyle, sosyalist devletler adı altında kendilerini halk demokrasisi ${ }^{50}$ diye tanımlayan yapılar oluştu.

15 yil önce yaşanan siyasal çöküşün ardından söz konusu halk demokrasileri - genelde anayasal devamlılıklarını olabildiğince korumaya çalışarak - marxist otoriter idare sistemlerini batılı anlamıyla demokratik devlet düzenine çevirdiler. ${ }^{51}$

Bu yeni demokrasilere giden yol yansımasını anayasalarında bulur. Letonya $^{52} 1922$ 'de benimsediği anayasasını yeniden yürürlüğe koydu, Estonya $^{53}$ ise 1938 anayasası temeli üzerine 1992 yılında yeni anayasasını inşa etti. Örneğin Macaristan ${ }^{54}$ (1989), Polonya ${ }^{55}$ (1997), Çek Cumhuriyeti ${ }^{56}$ ve Slovakya ${ }^{57}$ (1992) gibi bazı diğer devletler önce müzakereler, ardından geçiş dönemi için düzenlemeler yapmak durumunda kaldılar ve adım adım devletin hukuk düzenini yeni siyasal sistemlerine uyarladılar. Bu bağlamda Çekoslovakya 1992 yılında federal anayasasını terk etti ve Slovakya 
Cumhuriyeti ile Çek Cumhuriyeti yan yana yaşayan ayrı devletler olarak yapıland1 ${ }^{58}$.

Arnavutluk $^{59}$ (1991), Bulgaristan ${ }^{60} 1991$ ve Romanya ${ }^{61}$ (1991) gibi devletler çoğunluğu eskiden komünist olanlar tarafından yönlendirilen bir değişim yolunda ilerlemiştir. Böylesi bir yol eski Tito dönemi Yugoslavya'sında yeni devlet düzenlerine sıklıkla kanlı olaylarla ulaşabilmiştir.

\section{AB'nin Temel Düzeni/Yapısı}

Sistemler ve Avrupa devletlerinin bu anayasal düzenlerinin gelişmesi hakkında verilen bilgiler sadece ilgili devletlerin kendileri ve halkları için değil, aynı zamanda Avrupa devletlerin bütünlüğü, ama özellikle AB'nin Devletler Birliği için önemlidir. ${ }^{62}$

Önemlidir, çünkü 7 Şubat 1992 tarihli Avrupa Birliği Sözleşmesi'nin 6. maddesinde birliğin temelleri ile ilgili olarak "ïye devletlerin ortak anayasa gelenekleri”"ne sahip olduğu dile getirilir ve bunların, "birliğin hukukunun genel temel ilkeleri"nde ortaya çıktığı vurgulanır. ${ }^{63}$

Bu bağlamda Haziran 1993 'te Kopenhag' da ${ }^{64}$ Avrupa Konseyi'nin aldığı kararlar da animsanmalıdır, çünküi orada ilk defa bir devletin AB'ye üye olabilmesi için uygulanacak ölçütler ve aranacak önkoşullar ayrıntılarıyla tanımlanmıştır. Söz konusu koşullar ekonomik ve politik niteliklidir. Ekonomiyle ilgili olanlar işleyen bir piyasa ekonomisini ve $A B$ içindeki rekabetçi ve yarışmacı piyasa dinamiklerine uyabilmeyi gerektirirken politik olanlar "üyeliğe aday ülkenin demokratik ve anayasal hukuk düzeninin, insan haklarının ve azınlıkların sayılıp korunmasının teminatı olarak kurumsal bir sağlamlıkta olması gereği"ne işaret ederler. Bunlardan başka ayrıca topluluğun ortak birlik hukukunun da (acquis communautaires) devralınması gerekmektedir. ${ }^{65}$

$\mathrm{AB}$ 'nin bu ilkelerini ve koşullarını görünce bir devlet ile kıyaslama yapılmamalıdır. $\mathrm{AB}$ bir devlet değildir ve asla olamayacaktır. $\mathrm{O}$, daha ziyade bir devletler birliği, sui generis tarzı bir hukuk ortaklığıdır. Bu birlik üye devletlerin istenci ile yaşar ve gelişir. ${ }^{66}$

Hukuk, Avrupa Birliği’ni temellendirdi, birlik de diğer yönden hukukunu geliştiriyor. Hukuku konusunda Avrupa Birliği, üye ülkelerin 
birlik kurulurken ve geliştirilirken kararlaştırdığı ve öncelikli birlik hukuku denilen kurallara bağlıdır. Bu hukuk birliğin altyapısını oluşturur, kurumların yetkilerini belirler, görev alanlanını saptar ve uygulanacak prosedürleri tanımlar. ${ }^{67}$

$A B$ 'nin bu öncelikli birlik hukuku bağımsız bir devletin anayasa $h u k u k u^{68}$ ile karşılaştırıldığında aralarında özellikle iki bakımdan fark olduğu görülür: Devletin anayasa hukuku mutlak egemenlik koşulu ile tüm toplumsal alanlar için temel düzenlemeler içerir, oysa öncelikli birlik hukuku sadece sınırlı bazı yetkiler verir, ancak bunları oldukça ayrıntılı bir şekilde işler. ${ }^{69}$

Günümüzde benimsenmiş anlaysşa göre anayasalar ${ }^{70}$ kurucu bir parlamento vasıtasıyla ve bazen ona ilaveten bir halkoylaması aracılığıyla devlet oluşturma istencinin bir sonucudur. $A B$ hukuku anlaşma şeklinde ortaya çıkmış̧ır ve oluşma sürecinde hükümet temsilcileri tarafından şekillendirilmiştir. ${ }^{71}$

Birleşmiş Avrupa bir arada olmanın yeni bir biçimini hukuk aracılığıyla bulmak ve geçmişte ancak yan yana, hatta sıklıkla karşı karşıya olma şeklinde yürüyen ilişkileri aşmak için bu yola çıkmıştır. Birlik hukuku bir hukuk birliğinin ${ }^{72}$ temelini atmıştır. Hukuk birliği ise devletlerin işbirliği ile şekillenen değişik anlaşmalardan geçerek günümüzdeki halini almıştır: Başlangıçta 1958 yılında altı, 1995'ten sonra on beş ve 1 Mayıs 2004 tarihinden beri artık yirmi beş üye devlettir ${ }^{73}$ söz konu olan. Onlar hep birlikte Avrupa'nın hukuk düzenini biçimlendirmektedir.

Aslında belli bir ölçüde ortak bir Avrupa hukuk kültürü her zaman vardı. $\mathrm{Bu}$ zaman dilimi eskilere dayanan gelenekler nedeniyle ortaçağın sonlarından 18. yüzyıla değin uzanmaktadır.

Avrupa'nın hukuk uyumu uzun bir süre boyunca $\operatorname{Roma}^{74}$ ve kilise hukuku sayesinde sağlanmıştı. İkisi birlikte genel hukuk da denilen ius

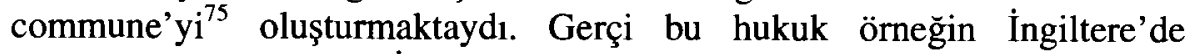
uygulanmıyordu, ancak İskoçya ve orta ile doğu Avrupa'nın tüm ulusları, sözgelimi Polonya ve Macaristan, onu benimsemişti, hatta bu ülkelerin üniversitelerinde okutulmaktaydı. Frankfurtlu hukuk hocası HELMUT COING Köln Hukuk Derneği üyelerinin huzurunda yaptığı ve 1989 yılında yayımlanan “Geçmişte, Günümüzde ve Gelecekte Avrupa'nın Ortak Yönleri” isimli konuşmasında ne kadar doğru bir başlık kullanmıştı: 
"Bologna'dan Brüksel'e". Şöyle diyordu konuşmasında: “Avrupa'da ortak bir hukuk bilimi vardı ve onun dili, önceleri tüm bilim dallarında olduğu gibi, Latinceydi. Örneğin 16. ve 17. yüzyıllarda her Alman hukukçu İtalyan, Fransız hatta İspanyol yazarlardan alıntılar yapardı., 76

Ulusal devletlerin kurulması ve aydınlanma akımının yaşanması ile birlikte devletlerin yasal düzenlerinde çeşitlenme ve derinleşmeler görüldü. Böylece hukuk bilimi de daha önemli bir konuma sahip olmaya başladı.

Avrupa'nın bütünleşme süreci ve hukuku bu hukuk geleneğine yaslanabilmişti. ${ }^{77}$ Hukuk aynı zamanda üye devletler ile birlik arasında birleştirici bir bağ işlevini de görmektedir.

Söz konusu birlik hukuku üye devletlerin arasında imzalanan anlaşmalar şeklinde meydana geldi, ardından ilgili devletlerin iç tüzükleri çerçevesinde görüşülüp tasdik edildi, sonra da Avrupa Adalet Divant ${ }^{78}$ tarafindan somutlaştırılıp uygulamaya konuldu. Hukukun bu şekilde yapılanması genelde genel hukuku, özelde temel hakları yakından etkilemektedir. Genel hukuk için örnek olarak meslek edinme ${ }^{79}$ ve mülk edinme ${ }^{80}$ özgürlüğü, özel haklar için ise teşebbüs ${ }^{81}$ ve sözleme yapma ${ }^{82}$ özgürlükleri sayılabilir.

Avrupa Adalet Divanı hukukun geliştirilmesine ekonomik alanın dışında da katkı sağlamıs ${ }^{83}$ ve örneğin özel meskenin dokunulmazlı̆g ${ }^{84}$ konusunda ya da aile yaşantısına saygı ilkesinin ${ }^{85}$ şekillenmesinde rol almıştır. Avrupa Adalet Divanı bundan başka bir dizi genel hukuk ilkesi ile birlik hukukunu da zenginleştirmiştir. Örnek olarak orantılllık ${ }^{86}$, hukuk emniyeti ${ }^{87}$ ve güvenin korunmasi $^{88}$ ilkeleri sayılabilir.

Bir hukuk birliği olarak Avrupa Birliği kuruluş sözleşmelerinin ${ }^{89}$ kendilerinden ve onların dönem dönem ilerletilmiş türevlerinden ${ }^{90}$ vücut bulur. Hukuk - ilk önce - ülkeler arasında iç sınırlanı bulunmayan serbest bir mekânı yaratmak için kullanılmıştır. Burada esas olarak dört özgürlük, yani malın, kişilerin, hizmetin ve sermayenin serbest dolaşımı, ${ }^{91}$ güvence altına alınmıştır. Avrupa'nın bu bütünleşmesi en başından beri ulusal sınırları aşan ortak bir politik düzenin kurulmasını amaçlayan bir işlevsellikle yürütülmüşstü. 1957 yılında imzalanan Avrupa Ekonomi Birliği Kuruluş Sözleşmesi'nin giriş bölümünde tanımlandığı gibi hedef, ekonomik birleşmenin ötesinde, "Avrupa uluslarının gittikçe daha çok kaynaşması için altyapıyı hazırlamak" "92 idi. 1992 Maastrich Anlaşması ile bu yaklaşım siyasal bir birliğin oluşturulmasını olanaklı kıldı. Sözleşme hukukunun 
geliştirilmesi yoluyla söz konusu birlik artık hukuk birliği olarak aynı zamanda hem ekonomik birlik oldu hem de ortak bir para birimini kullanmaya başladı ${ }^{93}$.

\section{Hukuk Birliği olarak AB'nin Gerekleri}

Hukuk birliği olarak AB'de üye devletlerin her biri konsey vasitasıyla hukukun teşkil ve tatbikine komisyon ile birlikte yön verir. Bu ortaklaşa yön veriş dolayısıyla devletlerin kendilerine özgü siyasal çıkarları ile Avrupa siyasetinin gerekleri arasında bir uyum sağlanır. Bu şekilde bir uyumun ise Montesquieu'nin anladığı anlamda giiçler ayrılığı ile ilgisi yoktur ve değişik işlevlerin tatbik edilmesi ile bölünmesinin kendine özgü, yeni bir biçimidir. ${ }^{94} \mathrm{AB}$ aynca konseyin ve komisyonun taşıdığı önem ve de Avrupa Parlamentosu'nun başlangıçta göreceli olarak küçük yetkilerle donanmış olması bakımından bir ölçüde yürütme zaafi ve demokrasi açı̆̆ı ${ }^{95}$ diye ifade edilen eksikliklerle karşı karşıyadır.

Avrupa düşüncesi bağlamında sık sık dile getirilen bu iki önemli eleştiri konusu yaşanabilir ve denetlenebilir durumdadır. Onlar özellikle demokratik anayasal devletlerin sahip oldukları gösterge ve ilkelerin devletlerarası birliğe transfer edilmesinden ötürü kendiliğinden doğmaktadır, çünkü bu transfer sirasında devletler birliği ile tek tek devletlerin düzenleri arasındaki ayrılıklar nedensellikleri ve gereklilikleri açısından yeterince sorgulanmamaktadırlar.

Bugüne dek hiç görülmemiş söz konusu devletler birliği - eskiden Avrupa Topluluğuydu, şimdi Avrupa Birliği oldu - Avrupa'nın bütünleşmesinin sonucu olarak anılan yürütme zaafı ve demokrasi açığı olmaksızın bu denli kısa bir zaman diliminde asla meydana gelemezdi. Çok sayida devlette başarıyla uygulanmasına karşın parlamenter idare sistemine dayalı demokratik anayasal düzen devletler ötesi boyutta, üstelik gittikçe artan üye sayısıyla, Avrupa'nın bütünleşmesini böylesine kısa zamanda kesinlikle hedefe ulaştıramazd..$^{96}$

AB, Avrupa'nın bütünleşmesi yönünde bir gelenek olmaksızın 2. Dünya Savaşından sonra kurulan sui genesis tarzı bir hukuk birliği olsa da, bir süper devlet değildir ve "anayasa sisteminde" köklü değişiklikler yapmadan olmayacaktır da. Ancak AB Avrupa'daki insanlar tarafindan yine de hukukun teşkili, hukuki icra, yargı ve güçler ayrılığı gibi aslında devletler için uygulanan ölçütlere göre değerlendirilmektedir. Kendini geliştirmesi 
gereken sadece $A B$ 'nin kurumları değildir, düşünce, irade ve hüküm verme süreçleri de gelişmektedir. Bu bağlamda bugüne dek $\mathrm{AB}$ üyesi tüm Avrupa devletleri arasında sağlanan birlikte olma tutumunun yerini üye ülkeler içindeki büyük devletlerin orta büyüklükteki ve küçük devletlere göre baskn olması hali almamalıdır. Çünkü bu durum, AB içinde bugüne dek yaşatılan ve Avrupa'nın bütünleşmesinin etkili bir göstergesi olan dayanışma anlayışını kökünden tehlikeye atardı. Çünkü AB'nin tüm üyeleri eşittir.

$\mathrm{Bu}$ ise $\mathrm{AB}$ içinde açık, yani herkesçe anlaşılabilecek bir yetki paylaşımını gerekli kılmaktadır. Açık yetki paylaşımı da birleşik Avrupa'da herkes için fazlasıyla önemli olan hukuk güvenliğini sağlayabilir.

Adem-i merkeziyet ilkesinin dikkate alınması ${ }^{97}$ dolayısıyla $\mathrm{AB}$ ancak birlik içinde çözülebilecek konularda etkin olur. Bunlara örnek olarak iç pazarın güvence altına alınması, ortak para biriminin kullanılması ve değerinin korunması, piyasada rekabet ortamını sağlayacak politikaların üretilmesi, ortak bir dışişleri ve savunma politikasının oluşturulması, çevre korumacılığı, sınır ötesi suçlarla mücadele, iltica ve mülteci politikaları gibi konular sayılabilir. Konseyde hangi düzenlemenin Avrupa genelinde, hangi düzenlemenin üye devletlerin iç işlerinde yapılacağına karar verenler iuye devletlerin kendileri olduğuna göre adem-i merkeziyet ilkesinin gözetilmesi de anonim bir Avrupa Birliğine değil, üye devletlere kalmış demektir. AB içinde olup biten neredeyse her şey üye devletlerin eliyle gerçekleşir ve olup biten neredeyse hiçbir şey üye devletlerin eli olmaksızın yürümez.

$A B$ içi müzakere ve karar verme süreçlerinde akıl ve olanaklar çerçevesinde şeffaflığın sağlanması ve konseyin kanun koyucu işleviyle toplandığı durumlarda kamuoyuna açık şekilde çalışması memnuniyet verici olurdu.

Genişlemiş bir Avrupa Birliğinin hareket alanının daralmaması gerektiği varsayımıyla ileri sürülen ve konseyde salt çoğunluğun oyuyla karara bağlanabilecek içeriklerin artması gerektiği şeklinde dile getirilen yaklaşım üzerinde düşünülmelidir. Sözleşme maddelerinin değiştirilmesi, genişleme ve öz kaynakların artırılması konularında şimdilik oy birliği ile karar verme geleneği sürdürülmelidir. Oy çokluğu ancak vergi ve sosyal politikalarının bazı bölümleriyle hukuk uyumumu alanında yararlı olurdu.

Parlamenter katılım ve denetim haklarının genişletilmesi yönünde harcanacak çabalar yararlı olurdu. Tüm parlamenter denetim olanakları 
ulusal meclislerle ve Avrupa Parlamentosuyla uyumlu hale getirilmelidir. Unutulmamalıdır ki Avrupa Parlamentosuna tanınan yetkilerinin genişletilmesi üye devletlerin ulusal parlamentolarına ait yetkilerin azalması sonucunu doğurabilir. Dolayısıyla ikisi arasındaki orantı birbirini tamamlayacak şekilde kurulmalıdır. Aynca birliğin konseyi kanun koyucu işlevliyle kararlar alacă̆ı zamanlarda ulusal parlamentolar önceden ve sistemli bir şekilde AB'nin bu yasama sürecine dahil edilmelidir. Avusturya açısından bu ilintinin genelde sağlandığı söylenebilir. ${ }^{98}$

Komisyon başkanının Avrupa Parlamentosu tarafından seçilmesi ve bütçe konusunda mutlak yetkinin ona devredilmesi aynca arzu edilen bir durumdur.

Süreçler basitleştirilmeli, daha şeffaf kılınmalı ve böylece AB vatandaşlanı için kolaylıkla anlaşılır hale getirilmelidir.

Vatandaşa yakınlık $\mathrm{AB}$ için de fazlasıyla önemlidir, çünkü birleşmiş Avrupa'da gittikçe daha çok insan gittikçe daha az insanın kendileri adına neyi nasıl yaptığını bilmemektedir.

Bu şeffaflık adına bir de sözleşmeler basitleştirilmeli, hukuk metinleri daha anlaşılır yapılmalı ve bilgi edinmenin yolları daha açık hale getirilmelidir.

Bunların tümü bir Avrupa kamuoyunun ${ }^{99}$ oluşması için önemli önkoşullardır ve bu kamuoyu çıkarlarını temsil edecek partiler ve sivil kuruluşlar, ayrıca Avrupa programları olan ve Avrupa'ya ulaşan kitle iletişim araçlarını talep etmektedir. Henüz bir $\mathrm{AB}$ radyosu ya da $\mathrm{AB}$ televizyon kanalı bile bulunmamaktadır! Oysa onlar, olabildiğince fazla insanın bir Avrupa bilincini ve bir Avrupa sorumluğunu geliştirmesi bakımından önemli önkoşullar olurdu. ${ }^{100}$

\section{Değerler Birliği olarak AB}

Hukuk birliği olarak yaşanan gelişme sürecinde son zamanlarda bir Avrupa anayasası ${ }^{101}$ beklentisiyle ilgili sorular gittikçe daha sık sorulur oldu. Avrupa Konseyi'nin Aralık 2000'de Nis kentinde düzenlediği ve Avrupa sözleşmelerinde köklü değişimler yapmayı öngördüğü, aynı zamanda $\mathrm{AB}$ için temel anayasa şartlarını karara bağlığı oturumun ardından bu sorular daha da çoğaldı. ${ }^{102} \mathrm{AB}$ içerik olarak böyle bir anayasaya 
öncelikli birlik hukukunda, yani kuruluş sözleşmeleri ve onların yine sözleşmelerle geliştirilen hallerinde zaten sahiptir. Ancak birlik diğer yönden bir anayasaya sahip değildir ve bir devletin anayasa hukukunda vücut bulduğu gibi bir anayasaya da biçimsel olarak sahip olamaz.

Bir devletin hukuk düzeniyle kıyaslandığında sözü geçen anlamda bir $\mathrm{AB}$ anayasasını görüşüp uygulamaya koyabilecek bir Avrupa Yasama Kurulu da yoktur zaten. Aynı şekilde Avrupa'nın tek bir halkı da yoktur, onun yerine tek tek devletlerin ayrı halkları vardır.

Yine de konsey tarafından oluşturulan anayasa çalışma grubu 2003 yazında Avrupa Birliği ile Avrupa Topluluğu sözleşmelerini tek bir metinde birleştiren bir anayasa sözleşmesinin taslağını takdim etti. Bu Avrupa Birliği anayasa taslağının - belki bazı yerleri biraz değiştirilerek - daha 2004 yılı içinde hem konsey hem Avrupa Parlamentosu tarafındàn benimseneceği beklenebilir. Taslağın ne kadar zamanda tasdik edileceği veya onun üye devletlerin kendi içlerindeki onay süreçlerinde reddedilmesi halinde ne gibi sonuçların doğabileceği bugünden kestirilemez. ${ }^{103}$

Ancak eğer AB kendini sadece işlevsellik ölçütü ile tanımlanan bir çıkar birliği olarak görseydi, o zaman birlik düşüncesi yanlış anlaşılmış olurdu. AB'nin temelini oluşturan şeyler aynı zamanda ilkelerdir ve AB Sözleşmesinin 6. maddesine göre bunlar özgürlük, demokrasi, insan haklarına ve temel özgürlüklerine saygı ile hukuk devleti ilkeleridir. AB aynı zamanda Avrupa İnsan Hakları Konvansiyonu'nun belirlediği temel hakları ve üye devletlerin ortak hukuk geleneğinden ileri gelen birlik hukukunun genel temel ilkelerini de benimsemektedir. Bunlardan başka $A B$, üyelerinin ulusal kimliklerini de tanımaktadır.

Temel ilkelerin ve temel hakların AB tarafından tanınması aslında bir takım değerlerin var olmasının, ayrıca onlanı bilincinde olunmasının ve onların korunmak istenmesinin sonucudur. Avrupa'nın bütünleşmesinin başında bir yanda Almanya, diğer yanda Fransa ile Benelüks ülkeleri arasınsa barışın tesisi niyeti bulunmaktaydı. Bütünleşme daha sonra, on yılı aşkın bir süre önce siyasal çöküşün yaşanmasına değin, komünist doğu bloğu ile uzun süren siyasal gerilime eşlik etti. Ne mutlu ki artık her iki neden de ortadan kalkmış durumdadır ve bu konu tarih sayfalarına karışmıştır. Günümüz Avrupa'sında birleşmeyi götüren itici güç rakip bir siyasal blok ile çatışma durumu olmamalıdır ve olamaz da. Onun yerine ülkeleri yakınlaştıran anlayıș ortak tinsel, dini ve kültürel köklerin bilinci 
olmalıdır. Daha ROBERT SCHUMAN ömrünün sonlarına doğru şöyle yazmıştı: "Avrupa, askeri bir ittifak ya da ekonomik bir birlik olmadan önce, kelimenin tam anlamıyla kültürel bir birlik olmalıdır." ${ }^{104} \mathrm{Bu}$ ise batılı dünyanın kültürünü şekillendiren ortak değerlerin insanların bilinç düzeyine çıkarılmasını gerekli kılmaktadır.

Avrupa için hazırlanan anayasa metninin giriş bölümünde batı dünyasının bu külttürü kast edilerek $\mathrm{AB}$ için "tinsel-dini ve ahlaki mirasının bilinci” vurgulanmakta, “Avrupa'nın kültürel, dini ve hümanist geleneklerinden beslenen ve mirasında yaşamayı sürdüren değerler"105 öne çıkarılmaktadır. Avrupa Birliği Temel Şartnamesi'nin girişinde ise şöyle denilmiştir: Tinsel-dini ve ahlaki mirasının bilinciyle birlik, insan onurunun ayrılmaz değerleri olan özgürlük, eşitlik ve dayanışma anlayışı üzerine inşa edilmiştir." ${ }^{106}$ Hem söz konusu değerler hem belirtilen temel haklar esasen eski Hıristiyan düşüncesinin laikleştirilmiş halleridir. Temel haklar insan onurundan, insan onuru ise tanrının insanı kendisine benzer şekilde yarattığı öğretisinden ileri gelmektedir. ${ }^{107}$

Birleşik Avrupa'nın bu düşünsel altyapısı AB'yi salt bir ekonomi ve para birliği olmaktan çıkanı onu aynı zamanda bir hukuk ve değerler birliği haline getirir. PAPA JOHANNES PAUL II. De bu durumu sıkça vurgulamıştır. Söz gelimi 24 Mart 2004 tarihinde Karl Ödülü'nün kendisine verilmesi sebebiyle Vatikan'da yaptığı şükran konuşmasında şöyle ifade etmiştir: "Söz konusu olan bencil ulusalcılıklardan annmış bir Avrupa'dır (...) Bu çatı altında bilimin, ekonominin ve toplumsal refahın büyük keşifleri anlamsız bir tüketime yönelmeyecek (...) ve bütünleşme gerçek özgürlüğün üzerine kurulacak." 108 Kendisi bu görüşü dile getirirken özellikle din özgürlügüünü vurgulamaktadır.

Bu bağlamda PAPA 2. JOHANNES PAUL'ün Vatikan'a atanan Türk konsolos OSMAN DURAK'a hitaben iki gün sonra, 26 Mart 2004'te, yaptığı konuşmadan bir alıntı da vermek istiyorum. Katolik kilisesinin başı burada, "Türkiye'nin Avrupa ile yeni münasebetler kurmaya hazırlandığı bir dönemde" kendisinin "tüm Katolik alem ile birlikte umutla sizin ülkenizdeki kilisenin hukuki statüsünün resmi Türk otoriteleri ve kurumları tarafından tanınacağını" beklediğıni belirtmiştir. ${ }^{109}$ Konuşmada Papa ayrıca "Türkiye'nin ulusal parlamentosunun insan haklanndan sorumlu altkurulunun geçen Eylül ayında Türkiye'de yaşayan Hıristiyanlann ve gayri Müslimlerin ortak dini ihtiyaçlarının karşılanmasıyla ilgili olarak 
verilen dilekçeye uygun göreceği şekilde olumlu bir yanıt vereceğini" umduğunu da vurgulamıştır. ${ }^{110}$

PAPA 2. JOHANNES PAUL böylelikle temel haklardan sayılan din özgürlügü konusunda Avrupa'da egemen olan ve doğal sayılan standartlara işaret etmiştir.

\section{Bir Anayasa Sözleşmesinin Taslağı Üzerine}

Sözü edilen amaçların $A B$ için Anayasa Sözleşmesi ve Temel Haklar Belgesi Taslağı'nın temelini oluşturması fazlasıyla sevindiricidir. AB temel haklar belgesinin artık - Avrupa İnsan Hakları Konvansiyonundan ve Avrupa Sosyal Belgesinden ${ }^{111}$ farklı olarak - bir temel haklar hukukunda AB içinde liberal demokratik ve toplumsal temel haklarla azınlık haklanını birleştirmesi olumlu bir yaklaşımdır.

Üye adayı devletlerin temsilcilerinin de katıldığı Avrupa'nın Geleceği Şurası çalışmalarına 28 Şubat 2002 tarihinde başlamış ve görevini 10 Temmuz 2003'te tamamlamıştır. ${ }^{112} \mathrm{AB}$ temel haklar belgesinin tarih itibariyle rüçhan hakkı vardır çünkü o, Avrupa Konseyinin Avrupa Birliği için bir temel haklar belgesinin oluşturulması ${ }^{113}$ yönünde Haziran 1999' da Köln'de aldığı ilke kararına dayanır ve 2 Ekim 2000 tarihinde tamamlanmıştır. ${ }^{114}$

$A B^{\prime}$ 'nin anayasa taslağında ${ }^{115}$ dikkat çeken yönler sözleşmelerin birleştirilmesi; sütun şeklindeki yapısının ortadan kaldınılması (birliğin tekil hukuk kimliği); birliğin temel haklar belgesinin kapsam içine alınması; hukuk güvenliğinin iyileştirilmesi; yetki alanlarının birlik ile üye devletler arasında daha olumlu şekilde bölüştürülmesi; birliğin yürütme ve karar verme süreçleri ile ilgili mekanizmalanın basitleştirilmesi; birliğin kurumları için daha şeffaf, verimli ve demokratik bir yapının ve işlevselliğin getirilmesi; ulusal meclislerin Avrupa ölçeğindeki karar mekanizmalarına daha dolaysız katılımının sağlanması; ayrıca birliğin dış işlerinde daha etkin olması; özgürlük, güvenlik ve hukuk alanlarının daha da büyütülmesi konusunda hareket yeteneğinin genişletilmesi; ekonomi ve para birliği (WWU) çerçevesinde yapılan atılımlar; ve Avrupa toplum modelinin temel öğelerinin dikkate alınması şeklinde sıralanabilir.

Birleşik Avrupa'nın temel düzeni aynntılarda nasıl biçimlenirse biçimlensin ve $A B$ 'nin üye sayısı ne yönde gelişirse gelişsin, $A B$ 'nin bir 
devlet olmadığı ve hiçbir zaman olamayacağı unutulmamalıdır. ${ }^{116}$ Onun görevlerinin genişletilmesi üye devletlerin sözleşmeler yoluyla yetkilerini devretmesine bağlıdır ki bu üye devletleri Federal Alman Anayasa Mahkemesi yerinde bir ifadeyle "birlik sözleşmelerinin efendileri" 117 diye tanımlamaktadır. AB ve topluluk hukuku devletler ötesi bir yapıya sahip olmanın, sınırlı tekil yetkilerle donatılmış olmanın ve adem-i merkeziyet ilkesine tabi olmanın gereklerine bağlıdır. ${ }^{118}$ Birlik hukukunun üye devletlerin hukuku ile ilintisi konusunda AB/AT hukukunun öncelikli olduğu savından hareket edilmektedir. ${ }^{19}$

Hukuksal gelişmelerinden bağımsız olarak $A B^{\prime}$ 'nin bir de müşsterek merkezli daireleri bulunur ki onlar kendi aralarında örtüş̧mez. Örneğin 1 Ocak 1999 tarihinden itibaren Avro'yu ulusal para birimi olarak kullanmaya başlayan belli sayıda - şu an bu sayı 12'ye ulaştı - devletin oluşturduğu bir daire vardır. Ondan başka iç politikalan, polisiye işler ve yabancılarla ilgili polisiye konularında işbirliği yapan yine belli sayıda devletin meydana getirdiği ikinci bir daire, yani Schengen dairesi, bulunmaktadır. Avrodairesi ile Schengen-dairesi üye devletlerin sayısı bakımından örtüşmemektedir. Onlardan başka ortak güvenlik ve savunma politikaları dairesi denilen bir kurgu daha vardır. Burada da yine belli sayıda üye devlet bir araya gelmiş durumdadır ve söz konusu dairelerin her biri kendi içinde alt dairelere - aynı zamanda Nato'ya üye olan devletler ve Nato'ya üye olmayan devletler şeklinde - bölünmüsş durumdadır. Sadece verilen örneklerden yola çıkarak bile Avrupa Birliği'nin çok katmanlı, dolayısıyla karmaşık bir kurgu olduğu görülebilir. Ayni saptama Avrupa'nın coğrafyası için de yapılabilir!

Coğrafyası itibariyle Avrupa kıtas ${ }^{120}$ Atlantik'ten Ural'lara kadar uzanır. Avrupa batı yönünde sahil şeridi ile sınırlanmışken doğu yönünde Alaska'ya kadar erişen Rusya'nın engin toprakları dolayısıyla açıktır. Avrupa coğrafyasının merkezinin neresi olduğu sorusu sorulduğunda verilmesi gereken yanıt ilginçtir: Merkez Ukrayna'daki Lemberg kenti dolaylarında bulunmaktadır.

\section{Avrupa ile Türkiye}

Avusturya'nın on katından fazla yüzölçümü ve yaklaşık 65 milyon nüfusuyla Türkiye ${ }^{I 2 I}$ sözü edilen Avrupa kıtası ile iki, hatta üç kıtanın kesiştiği bir noktada karşı karşıta bulunmaktadır. Bir de doğrudan Avrupa'da yaşayan 20 milyon dolayında Müslüman'1 da göz ardı etmemek 
gerekir, çünkü onlar aracılığıyla Türkiye Avrupa'nın çok kültürlü yapısına katılmaktadır. ${ }^{122}$

Bu bağlamda ve onun ötesinde Türkiye'nin genelde bütün özgür dünyanın, özelde Avrupa'nın ${ }^{123}$ birçok uluslar arası kuruluşunun, sözgelimi Nato'nun, bir üyesi olduğunu da anımsatmalıdır. Türkiye'nin komünizm zamanındaki önemli stratejik işlevi unutulmamalıdır. Güvenlik politikaları bakımından taşıdığı rol ise, hele günümüzde içinde bulunduğumuz acımasız terörizm ortamında, oldukça açıktır!

Türkiye aynca Avrupa'nın yaşamakta olduğu hukuki sürece de katılma çabası içindedir. ${ }^{124}$ Avrupa İnsan Hakları Konvansiyonu'nu, ayrıca vatandaşlık haklan ve siyasal haklar ile toplumsal ve ekonomik hakları içeren uluslararası sözleşmeleri imzalayıp onaylaması bu çabanın göstergelerindendir. ${ }^{125}$ Ancak ne yazık ki İnsan Haklariyla İlgili Avrupa Adalet Divanı'nın bütün kararlan uygulamaya konulmamakta ve tazminatlar ödenmektedir. ${ }^{126}$

Her devletin demokrasi, anayasal devlet düzeni ve hukuk devleti yönünde kendine özgü bir gelişme yolu vardır. Türkiye'nin de öyle. Bu bağlamda Türkiye'nin AB hukuku ile uyum sağlama, yargının bağımsızlığı ve etkinliğinin artırılması, yürütmede reform yapma, rüşvetle mücadele etme ve de sivil güç ile askeri güç arasında orantı kurma çabalanını saymak gerekir. ${ }^{127}$

Dahası, Türkiye ile AB'nin 1 Ocak 1996 tarihinden beri yürürlükte olan gümrük birliği anlaşmasını, 26 Şubat 2002 tarihinde imzalanan çerçeve anlaşmaları doğrultusunda Türkiye'nin $\mathrm{AB}$ ölçeğinde yürütülen, örneğin ayrımcılıkla ve toplumsal dışlama ile mücadele programı gibi çok sayıda topluluk programına katıldığını da belirtmek isterim. Ortaklığın önceliklerinin gerçekleştirilmesi doğrultusunda hizmet sektöründeki serbestlik, istatistik, toplumsal politikalar, enerji, sanayi politikası, tüketiciyi koruma ve sağlık alanlarında elde edilen kısmi başarılan da görmek gerekir. $^{128}$

Bizler Avusturya'da Türkiye'nin çabalanını ve kaydettiği gelişmeyi ilişskilerimizin geleneği ${ }^{129}$ bağlaminda izliyor, Türkiye'nin bir istikrar faktörï olarak önemini, Yunanistan ile kurulan yeni ilişsileri ve Kıbrıs konusundaki çabalarını kabul ediyoruz. 
Avusturya'nın Türkiye'deki reform sürecine desteği örneğin bir yakınlaştırma vasıtası olan ve Twinning adı verilen uygulama çerçevesinde sağladığı katkı ile somut olarak belgelenmektedir. AB'nin iki milyon Avro kaynak sağlayarak desteklediği bu iki yıllık proje Avusturya ile Türkiye'nin işbirliği ile yürümekte ve aslında çağdaş olan Türk hukukunun bir takım meslek içi eğitimlerle, bazı kararnamelerin hazırlanmasıyla, ayrıca polis ile adalet birimleri ve avukatlar arasındaki işbirliğinin artırılmasıyla insan haklarına uygun hale getirilmesini amaçlamaktadır.

Somut olarak bu proje boyunca 200 erkek ve bayan polis antrenörü ile 800 bayan polis memurunun eğitilmesi, ayrıca deneme mahiyetinde 30 sorgulama odasının uygun şekilde donatılması öngörülmüş̧ür. Diğer tüm projelerde olduğu gibi burada da bilimsel know-how ile uygulamadan elde edilmiş deneyimler arsında doğru orantıların kurulması çok önemlidir. Sivil toplum kuruluşlarının güçlenmesine katkı sağlamak üzere devlet güdümünde olmayan kuruluşların, örneğin Türk avukatlar birliklerinin de proje kapsamına alınmasının ayrı bir önemi vardır.

Avrupa'nın yeni düzeni bağlamında işlediğimiz Türkiye - Avusturya münasebetlerinin günümüze ait bu örnekleri bize geçmişin derinliklerinden kalan geleneğimizi unutturmamalıdır. Örneğin 1200 yılı aşkın bir süre önce, tam olarak 803 yılında, Kayser Büyük Şarl'ın (Şarlman) Salzburg'ta Bizans'ın elçileriyle buluşması ${ }^{130}, 250$ yıl önce IMPPARATORIÇE MARİA TEREZA'nın Viyana'da Şarkiyat Akademisini kurmasi ${ }^{131}$ - ki daha sonraları burada Türkoloji ve Arap Kültürü Merkezleri de doğdu - ve yazar FRANZ GRILLPARZER' in ${ }^{132}$ İstanbul, Truva ve İzmir'e yaptığı geziler bu geleneğin en fazla bilinen satırbaşlarındandır. Müzik, başkalarının yanı sıra "Saraydan Kız Kaçırma" ve WOLFGANG AMADEUS MOZART' $\mathbf{n n}^{133}$ Türk Marşı gibi eserlerle zenginleştirildi, gastronomi ise Türk kahvesiyle.

Ülkelerimiz arasındaki en etkili insani ilişki ise herhalde eğitim öğretim düzleminde sürdürülmektedir. Üniversitelerimiz arasında kurulmuş bulunan akademik bağlar ile İstanbul'da uzun yıllardır hizmet veren Avusturya Lisesi ${ }^{134}$ güzel örneklerdir. Bu okulun en ünlü mezunlarından biri olan eski başbakan Mesut Yılmaz'ı geçtiğimiz yaz mevsiminde Salzburg'ta Dr. Herbert Batlin Enstitüsü'nde etkileyici Avrupa konuşmasını yaparken izleme şansım oldu. ${ }^{135}$ Onun sözlerinden bir alıntı yapmak istiyorum: "Türkiye, kriz zamanlarında uzaklara erişebilen bir ok, barış zamanlarında görkemli bir köprü’”136 olabilir. 
Güvenli köprüler ise ancak sağlam zeminler üzerine kurulabilir ve geleceğe giden doğru yolu ancak nereden geldiğini ve kökleri itibariyle nereye ait olduğunu bilenler, aynı zamanda koşulları ve olanaklanı ölçüsünde ne yönde ne kadar ilerleyebileceğini kestirebilenler bulabilir. Dolayısıyla birleşmiş Avrupa'nın yeni düzeninde ortaklık anlayışı içinde bu yolu kestirmeye çalışmalıyız. Daha ziyade genel bir ifadeyle dile getirilen bu saptama özelde Hıristiyan geleneği ile Avrupa ${ }^{137}$, Müslüman halkı ile de Türkiye $^{138}$ için geçerlidir.

Avrupa'daki birleşmeye katılan her devlet, dolayısıyla şu anki yirmi beşler de öyle, kendi varlığının gerekleri, üstesinden gelmek durumunda olduğu tarihi ve geleceğe dönük beklentileri ile yüzleşmek zorundadır. Bu gerçeği dikkate alan Maastrich Anlaşması "Avrupa kıtasındaki bölünmüşlüğü aşmanın tarihi önemini ve geleceğin Avrupa'sının şekillenmesi için sağlam temellerin atılması gereği” ${ }^{139}{ }^{139}$ vurgulamaktadır.

Avrupa'nın bu bütünleşme yolunda Avrupa'nın İkinci Dünya Savaşı sonrasında yaşadığı bölünme tersine çevrilmiş ve Avrupa, Avrupa kıtası üzerindeki ve onun ötesinde halklar ailesi içindeki hareket etme ve karar verme özgürlüğünü yeniden kazanmıştır. Bu birleşmiş Avrupa kurgusunun sahip olduğu olanaklarla AB'nin bu kıta üzerinde her türlü yanlış Avrupa merkeziyetçiliğinden uzak durarak aynı zamanda bir barış ve güvenlik birliği olması, böylelikle gittikçe yayılan terörizme ${ }^{140}$ de karşı durarak dünyanın esenliğine de yardımcı olması dileğiyle...

\section{Sonnotlar}

Bkz. Dieter Grimm: „Verfassung“; Yayımlandığı yer: Geschichtliche Grundbegriffe, Historisches Lexikon zur politisch-sozialen Sprache in Deutschland; Yayımlayanlar: Otto Brunner, Werner Conze, Reinhart Koselleck; 6. cilt, Stuttgart 1990, s. 831 vd.

2 Aristoteles, Politik I, 1253.

${ }^{3}$ Ayrıntılar için bkz Gerhard Dulckeit, Fritz Schwarz ve Wolfgang Waldstein: Römische Rechtsgeschichte, 9. bask1, Münih 1995, s. 31 vd.

${ }^{4}$ Avusturya ile ilgili olarak bkz Herbert Schambeck, Von den Staatszwecken Österreichs, Parlamentarismus und öffentliches Recht in Österreich - Entwicklung und Gegenwartsprobleme, Erster Teilband, yayımlayan kendisi, Berlin 1993, s. 3 vd. 
5 Bilgi için bkz Hans R. Klecatsky, „Die verfassungsrechtliche Problematik des modernen Wirtschaftsstaates“, Grazer Universitätsreden Nr. 7/1968 ayrica Karl Korinek und Michael Holoubek, Grundlagen staatlicher Privatwirtschaftsverwaltung, verfassungsrechtliche und einfachgesetzliche Rahmenbedingungen nicht hoheitlicher Verwaltung, Graz 1993.

${ }^{6}$ Aristoteles, a.g.y., 1289a 26-31 ve bilgi için Grimm, a.g.y. s. 833 vd

${ }^{7}$ Cicero, De re publica 1, 26; 1, 44; 1, 28; 1, 45; 1, 34 ile 1, 20 ve aynca Grimm, a.g.y. s. 836 .

${ }^{8}$ Grimm, a.g.y. s.836.

9 Bilgi için bkz Herbert Schambeck, „Der Verfassungsbegriff und seine Entwicklung“; Yayımlandığı yer: Festschrift für Hans Kelsen zum 90. Geburtstag; Yayımlayanlar: Adolf J. Merkl, René Marcic, Alfred Verdross ve Robert Walter, Viyana 1971, s. 211 vd; Yeni bask1: Aynı yazar, Der Staat und seine Ordnung, ausgewählte Beiträge zur Staatslehre und zum Staatsrecht, yayımc1: Johannes Hengstschläger, Viyana 2002, s. 45 ve devam1.

${ }^{10} \mathrm{Bkz}$ Georg Jellinek, Allgemeine Staatslehre, 3. bask1, 6. yeni basım, Darmstadt 1959, s. 504 vd., özellikle s. 508 vd.

${ }^{11}$ Bilgi için Carl J. Friedrich, Der Verfassungsstaat der Neuzeit, Berlin - Göttingen - Heidelberg 1953, s. 135 vd.

12 Bkz Samuel Eliot Morison, Henry Steele Commager ve William E. Leuchtenburg, The Growth of the American Republic, Seventh Edition, Volume One, New York - Oxford 1980, s. 14 vd., ayrica Dokumente zur Geschichte der Vereinigten Staaten von Amerika, Herbert Schambek'in önsözü ile; Yayımlayanlar: Herbert Schambeck, Helmut Widder ve Marcus Bergmann, Berlin 1993, özellikle s. $10 \mathrm{vd}$.

${ }^{13}$ Dokümanlar, a.g.y., s. 19 vd.

${ }^{14}$ Dokümanlar, a.g.y., s. 166 vd.

15 Bkz Jellinek, a.g.y., s. 517 vd., ayrica Klaus Stern, „Grundideen europäischamerikanischer Verfassungsstaatlichkeit", Schriftenreihe der Juristischen Gesellschaft zu Berlin, Heft 91, Berlin - New York 1984, s. 12 vd.

16 Bkz Oskar Wener Kägi, Zur Entstehung, Wandlung und Problematik der Gewaltenteilung, ein Beitrag zur Verfassungsgeschichte und Verfassungslehre, Zürih 1937.

${ }^{17}$ Hesiod, Werke und Tage, dize $213 \mathrm{vd}$.

${ }^{18}$ Polybios, Historiae VI, 11 - 15.

${ }^{19}$ Aristoteles, Politik IV 1298a. 
${ }^{20}$ John Locke, Two Treatises of Civil Government, 1690.

${ }^{21}$ Montesquieu, De l'esprit des lois, 1748, IX/2 ve 3.

${ }^{22}$ Ayrıntılı bili için Herbert Schambeck, Regierung und Kontrolle in Österreich, Berlin 1997.

23 Bkz Herbert Schambeck, „Zur Idee und den heutigen Formen der Gewaltenteilung im Staat", Zeitschrift für Schweizerisches Recht, N.F. cilt 115, 1. Halbband Heft 5, cilt 137, 1996, s. 423 vd.; yeni baskı: aynı yazar, Der Staat und seine Ordnung, s. 141 vd., özellikle s. 154 vd.

${ }^{24}$ Konu için bkz Klaus Stern, Das Staatsrecht der Bundesrepublik Deutschland, cilt I, 2. baskı, Münih 1984 ve aynca Handbuch des Staatsrechts der Bundesrepublik Deutschland, yayımlayan Josef Isensee ve Paul Kirchhof, cilt I, Heidelberg 1987.

25 Temel olarak Hans R. Klecatsky, „Bundes-Verfassungsgesetz und Bundesverfassungsrecht“", yayımlandığı yer: Das österreichische BundesVerfassungsgesetz und seine Entwicklung, yayımlayan Herbert Schambeck, Berlin 1980 , s. 83 vd.

${ }^{26}$ Bkz örneğin Ludwig K. Adamovich, Bernd-Christian Funk, Gerhart Holzinger, "Österreichisches Staatsrecht“, cilt 1: Grundlagen, Viyana - New York 1997, cilt 2: Staatsrechtliche Organisation, Viyana - New York 1998 ayrica Band 3: Grundrechte, Viyana - New York 2003 ve Theo Öhlinger, Verfassungsrecht, 5.baskı, Viyana 2003.

${ }^{27}$ Bkz Peter Badura, „Staat und Verfassung in Europa“, yayımlandığı yer: Modern Theories of Public Law Revisted, Festschrift in Honor of Prof. Dr. Yuch Sheng Weng's 70th Birthday, Taipeh 2003, s. $1043 \mathrm{vd.}$

${ }^{28}$ Bilgi için örneğin: „Verfassungen der EU-Mitgliedstaaten“, Textausgabe mit einer Einführung und einem Sachverzeichnis von Adolf Kimmel und Christiane Kimmel, 5. baskı, Münih 2000.

29 Arıntilar için: Herbert Schambeck, "Verfassungsrechtliche Tendenzen europäischer Demokratien", yayımlandığı yer, Zu Politik und Recht, Ansprachen, Reden, Vorlesungen und Vorträge, yayımlayanlar: Österreichische Parlamentarische Gesellschaft işbirliği ile der Präsident des Nationalrates und der Präsident des Bundesrates, Viyana 1999, s. 97 vd.

${ }^{30}$ Verfassungen der EU-Mitgliedstaaten (AB üye ülkelerinin anayasaları), s. 277 vd.

${ }^{31}$ Bkz Felix Ermacora, "Zur Entstehung", yayımlandığı yer: Das österreichische Bundes-Verfassungsgesetz und seine Entwicklung, s. 3 vd. 
32 Bkz Die östereichische Bundesverassung und Hans Kelsen, Analysen und Materialien zum 100. Geburtstag von Hans Kelsen, yayımlayan Felix Ermacora, Christiane Wirth'in işbirliği ile, Viyana 1982.

${ }^{33}$ Bilgi için Walter Berka, Die Grundrechte, Viyana - New York 1999, aynı yazar: Lehrbuch der Grundrechte, Viyana - New York 2000, ayrica Adamovich/Funk/Holzinger, "Österreichisches Staatsrecht”, cilt 3, Grundrechte.

${ }^{34}$ BGBI. No. 210/1958.

${ }^{35}$ 4.3.1964 tarihli BVG, BGBI no. 59/1964.

${ }^{36}$ RGTBI No. $142 / 1867$.

${ }^{37}$ Verfassungen der EU-Mitgliedstaaten, a.g.y., s. 41 vd.

${ }^{38}$ Verfassungen der EU-Mitgliedstaaten, a.g.y., s. $487 \mathrm{vd}$.

${ }^{39}$ Verfassungen der EU-Mitgliedstaaten, a.g.y., s. 293 vd.

40 Bkz Klaus Stern, "Weltweite Verfassungsentwicklungen und neue Verfassungen", Comparative Law Vol. 18 (2001), Nihon University Tokyo, s. 99 vd.

${ }^{41}$ Verfassungen der EU-Mitgliedstaaten, a.g.y., s. 141 vd.

${ }^{42}$ Verfassungen der EU-Mitgliedstaaten, a.g.y., s. 249 vd.

${ }^{43}$ Verfassungen der EU-Mitgliedstaaten, a.g.y., s. 57 vd.

44 Bilgi için bkz Deutsche Wiedervereinigung, Die Rechtseinheit, Arbeitskreis Staats- und Verfassungsrecht, cilt V Zehn Jahre Deutsche Einheit, yayımlayan Klaus Stern, Köln - Berlin - Bonn - Münih 2001.

${ }^{45}$ Verfassungen der EU-Mitgliedstaaten, a.g.y., s. $163 \mathrm{vd.}$

${ }^{46}$ Verfassungen der EU-Mitgliedstaaten, a.g.y., s. $402 \mathrm{vd}$.

${ }^{47}$ Verfassungen der EU-Mitgliedstaaten, a.g.y., s. $519 \mathrm{vd}$.

${ }^{48}$ Verfassungen der EU-Mitgliedstaaten, a.g.y., s. 213 vd.

${ }^{49}$ Verfassungen der EU-Mitgliedstaaten, a.g.y., s. $141 \mathrm{vd}$.

50 Bkz Peter Häberle, „Dokumentation von Verfassungsentwürfen und Verfassungen ehemals sozialistischer Staaten in (Süd-) Osteuropa und Asien, yayımlandığ1 yer: Jahrbuch des öffentlichen Rechts der Gegenwart, N.F./cilt 43, Tübingen 1995, s. 184 vd; devam yazısı: Jahrbuch des öffentlichen Rechts der Gegenwart N.F./cilt 44, Tübingen 1996, s. 326 vd., ayrica Jahrbuch des öffentlichen Rechts der Gegenwart, N.F./cilt45, Tübingen 1997, s. 178 vd., ve Jahrbuch des öffentlichen Rechts der Gegenwart, N.F./ cilt 46, Tübingen 1998, s. $124 \mathrm{vd}$. 
${ }^{51}$ Bkz Herber Schambeck, „Politik und Verfassungsordnung postkommunistischer Staaten Mittel- und Osteuropas“, yayımlandı̆̆1 yer: Politik und Recht, s. 121 vd.

52 "Verfassung der Republik Lettland vom 15. Februar 1922 i.d.F. der Verfassungsgesetze vom 21. August 1991, 11. Dezember 1991 und 6. Juli 1993", 1922 yılına ait anayasanın İngilizce çevirisi, basıldığı yer: Jahrbuch des öffentlichen Rechts der Gegenwart, N.F. cilt 44, Tübingen 1996, s. 419 vd.

53 "Verfassung (Grundgesetz) der Estnischen Republik vom 10. April 1992, Einführungsgesetz des Parlaments vom 13. Mai 1992 und Verfassungsreferendum vom 28. Juni 1992, in Kraft getreten am 3. Juli 1992"; yayımlandığ 1 yer: Riigi teataja 1992, No. 26, Pos. 349; İngilizce çevirisi: Jahrbuch des öffentlichen Rechts der Gegenwart, N.F. cilt 43, Tübingen 1995, s. 306 vd.

54 ,Verfassung der Ungarischen Republik, Verabschiedung einer Totalrevision der Verfassung von 1949/72 durch Parlamentsbeschluß vom 18. Oktober 1989, in Kraft getreten am 23. Oktober 1989“, yayımlandığ1 yer: Magyar Közöny 1990, No. 59, s. 1741 .

55 Verfassung der Republik Polen vom 2. April 1997; İngilizce çevirisi: The Constitution of The Republic of Poland, yaymlayan: Bureau of Research, Chancellory of the Sejm, Warshaw 1997; ayrica Boguslaw Banaszak/Machal Rynkowski, „Die neue polnische Verfassung vom 2. April 1997“, Monatshefte für osteuropäisches Recht 1997, s. 407 vd.

56 „Verfassung der Tschechischen Republik vom 16. Dezember 1992, in Kraft getreten am 1. Jänner 1993“; yayımlandığ1 yer: Sbirka zàkonu Ceské republiky 1993, No.1; Almanca çevirisi: Jahrbuch des öffentlichen Rechts der Gegenwart, N.F. cilt 44, Tübingen 1996, s. 458 vd.

57 „Verfassung der Slowakischen Republik vom 1. September 1992, in Kraft getreten am 1. Oktober 1992 (teiweise 1. Jänner 1993)“; yayımlandığı yer: Sbirka zàkonu Ceské a Slovenské Federativni Republiky No 460, 1992; İngilizce çevirisini yayılandığı yer: Jahrbuch des öffentlichen Rechts der Gegenwart, N.F./ cilt 44, Tübingen 1996, s. $478 \mathrm{vd}$.

${ }^{58}$ Bkz Herbert Schambeck, Zu Politik und Recht, Viyana 1999, s. 126.

59 „Gesetz über die Hauptvorschriften der Verfassung der Republik Albanien vom 29. April 1991"; yayımlandığı yer: Gazeta Zyrtare e Republikes se Shqiperise 1991, No. 4, s.145, 160; İngilizce olarak anayasa taslağı için: Jahrbuch des öffentlichen Rechts der Gegenwart, N.F./ cilt 44, Tübingen 1996, s. 458 vd.

60 „Verfassung der Republik Bulgarien vom 12. Juli 1991“, yayımlandığı yer: 13 Temmuz 1991 tarihli Darzaven Vestnik (resmi yayın) No. 56; yürürlüğe giriş tarihi: 13 Temmuz 1991; fransızca çevirisi için: Jahrbuch des öffentlichen Rechts der Gegenwart, N.F. /cilt 44, Tübingen 1996, s. 497 vd. 
61 „Verfassung der Republik Rumänien vom 21. November 1991, Verfassungsreferendum vom 8. Dezember 1991, in Kraft getreten am 8. Dezember 1991“; yayımlandı̆̆ yer: 21 Kasım 1991 tarihli Monitorul Oficial No. 233; Ingilizce çevirisi: The Constitution of Romania 1991, yayımlayan Monitorul Oficial, 2. basım, Bükreș 1995.

62 „Entscheidung des Bundesverfassungsgerichts der Bundesrepublik Deutschland 89, 155“, ayrıca konu için: Paul Kirchhof „Das Maastricht-Urteil des Bundesverfassungsgerichtes“, yayımland1ğı yer: Der Staatenverbund der Europäischen Union, yayımlayanlar Peter Hommelhoff ve Paul Kirchhof, Heidelberg 1994, s. 11 vd.

${ }^{63}$ Bkz Europarecht Textausgabe mit einer Einführung von Claus Dieter Classen, 18. basım, Münih, s. 5.

${ }^{64}$ Tagung der Staats- und Regierungschefs der Europäischen Gemeinschaft am 21. und 22. Juni 1993; ABI 1993, No. C 194, s. 216 vd.

${ }^{65}$ Bkz Peter Fischer, Heribert Franz Köck ve Margit Karollus, Europarecht, 4. basım, Viyana 2002, s. 52.

${ }^{66}$ Bkz. Europa als politische Idee und als rechtliche Form, yayımlayan: Josef İsensee, Berlin 1993, orada özellikle: Paul Kirchhof: „Europäische Einigung und der Verfassungsstaat der Bundesrepublik Deutschland“", s. 63 vd.

${ }^{67}$ Hukuk birliği olarak Avrupa Birliği için bkz Bea Verschraegen, yayımlandığı yer: Henrich Neisser, Bea Verschraegen: Die Europäische Union, Anspruch und Wirklichkeit, Viyana 2001, s. 245 vd.

${ }^{68}$ Bkz Friedrich Koja: Allgemeine Staatslehre, Viyana 1993, s. 105 vd.; Peter Pernthaler: Allgemeine Staatslehre und Verfassungslehre, 2. basım, Viyana - New York 1996, ayrıca Günther Winkler: Vom Wesen und Wert der Verfassung, s. 1 vd. Ve „Über einige Eigenarten der Verfassung“, s. 19 vd., yayımlandığı yer: Rechtswissenschaft und Politik, Viyana - New York 1998.

${ }^{69}$ Bkz Dieter Grimm, Braucht Europa eine Verfassung?, Münih 1995, s. 28 vd.

${ }^{70}$ Esas olarak Oskar Werner Kägi: Die Verfassung als rechtliche Grundordnung des Staates. Untersuchungen über die Entwicklungstendenzen im modernen Verfassungsrecht, Zürih 1945, yeni basımı Darmstadt 1971, ayrica Verfassung, Beiträge zur Verfassungstheorie, yayımlayan Manfred Friedrich, Darmstadt 1978.

${ }^{71}$ Ayrıntılar için Fischer/Köck/Karollus, a.g.y. s. 303 vd.

72 Bilgi için: Die Europäische Union als Rechtsgemeinschaft, yayımlayanlar Wolfgang Blomeyer ve Karl Albrecht Schachtschneider, Berlin 1995; ayrica Manfred Zuleeg „Die Europäische Gemeinschaft als Rechtsgemeinschaft“, yayımlandığı yer Neue Juristische Wochenschrift 1994, s. 545 vd. 
${ }^{73}$ „Europa der 25 - Chancen und Risiken“, Europäische Rundschau 2004, özel say1

${ }^{74}$ Bkz Paul Koschaker, Europa und das Römische Recht, 4. basım, Münih ve Berlin 1966.

${ }^{75}$ Bkz Franz Wieacker, Privatrechtsgeschichte der Neuzeit, 2. basım, Göttingen 1967.

76 Helmut Coing „Von Bologna bis Brüssel. Europäische Gemeinsankeiten in Vergangenheit, gegenwart und Zukunft“, Kölner Juristische Gesellschaft, cilt 9, Bergisch Gladbach-Köln 1989, s.8.

${ }^{77}$ Aynntılar için Herbert Schambeck ,Rechtsbewusstsein und Rechtssicherheit im integrierten Europa“, yayımlandığı yer: Zu Politik und Recht, s. 213 vd.

${ }^{78}$ Bkz Fischer/Köck/Karollus, a.g.y. s. 560 vd.

${ }^{79}$ EuGH Slg. (Avrupa Adalet Divanı kararları) 1979, 3727 (3750).

${ }^{80}$ EuGH Slg. (Avrupa Adalet Divanı kararlanı) 1979, 3727 (3745-3749).

${ }^{81}$ EuGH Slg. (Avrupa Adalet Divanı kararları) 1970, 1125 (1134, 1137).

${ }^{82}$ EuGH Slg. (Avrupa Adalet Divanı kararları) I 1991, 3617 (3637 vd.).

${ }^{83}$ Konu için Wassilios Skouris, "Demokratie und Verfassungsgerichtsbarkeit aus der Sicht des Europäischen Gerichtshofes“, yayımlandı̆̆ı yer: Dimensionen des modernen Verfassungsstaates, Symposium zum 6. Geburtstag von Karl Korinek, yayımlayanlar: Michael Holoubek, Brigitte Gutknecht, Stephan Schwarzer ve Andrea Martin, Viyana - New York 2002, s. 151 vd.

${ }^{84}$ EuGH Slg. (Avrupa Adalet Divanı kararları) 2859 (2924).

${ }^{85}$ EuGH Slg. (Avrupa Adalet Divanı kararları) 1989, 1263 (1290).

${ }^{86}$ EuGH Slg. (Avrupa Adalet Divanı kararları) 1977, 1211 (1220 vd.).

${ }^{87}$ EuGH Slg. (Avrupa Adalet Divanı kararları) 1989, 2237.

${ }^{88}$ EuGH Slg. (Avrupa Adalet Divanı kararları) 1975, 533 (549).

${ }^{89}$ Konu için bkz Un changement d'espérance, La Déclaration du 9 mai 1950 Jean Monnet-Robert Schuman, yaymmlayanlar: Henri Rieben, Martin Nathusius, Francoise Nicod ve Claire Champerio-Tixier, Lozan 2000.

${ }^{90}$ Bkz Franz Knipping, Roma, 25 Mart 1957, Die Einigung Europas, Münih 2004.

${ }^{91}$ Vertrag zur Gründung der Europäischen Gemeinschaft vom 25. März 1957 (=25 Mart 1957 tarihli Avrupa Birliği Kuruluş Sözleşmesi),Titel III, AA. 39-60; Europarecht s. $40 \mathrm{vd}$. 
92 Präambel des Vertrages zur Gründung der Europäischen Gemeinschaft, Europarecht, s.29.

${ }^{93}$ Konu için Hans Tietmeyer, Währungsstabilität für Europa, Beiträge, Reden und Dokumente zur europäischen Währungsintegration aus vier Jahrzehnten, BadenBaden 1996 ve aynı yazarın „Probleme einer europäischen Währungsunion und Notenbank", yayımlandığı yer: Europa als politische Idee und als rechtliche Form, s. $35 \mathrm{vd}$.

${ }^{94}$ Bkz Neisser, „Das politische System der europäischen Nation“, yayımlandığı yer: Neisser/Verschraengen, a.g.y., s.40 vd.

${ }^{95}$ Konu hakkında bili için Fischer/Köck/Karollus, a.g.y. s. 57 vd.

96 Ayrıntılar için Herbert Schambeck, „Über die Idee einer EU-Verfassung“, yayımlandığ1 yer: Ein Leben in Praxis und Wissenschaft, Festschrift Walter Barfuß zum 65. Geburtstag, yayımlayanlar: Carl Baudenbacher, Heinz Mayer ve Hellwig Torggler, Viyana 2002, s. 232 vd.

${ }^{97}$ Bkz örneğin Brigitte Gutknecht, „Das Subsidiaritätsprinzip als Grundsatz des Europarechts“, yayımlandığı yer: Für Staat und Recht, Festschrift für Herbert Schambeck, yayımlayanlar Johannes Hengstschläger, Heribert F. Köck, Karl Korinek, Klaus Stern und Antonio Truyol y Serra, Berlin 1994, s. 921 vd.; ayrica Fischer/Köck/Karollus, a.g.y. s. 472 vd.

${ }^{98}$ Konu için bkz Adamovich/Funk/Holzinger, a.g.y. s. 254 vd; Matthias Tschirf, „Der Bundesstaat und die Europäische Integration, yayımlandığ yer: Bundesstaat und Bundesrat in Österreich, yayımlayan Herbert Schambeck, 2. basım, Viyana 2003, s. 221 vd.; ayrica Öhlinger, Verfassungsrecht, s. 96 vd.

99 Ayrıntılar için bkz Herbert Schambeck, „Von der Bedeutung der Medien für Europa“, yayımlandığı yer: Wir in Europa, Albert Schaf zum 65. Geburttag, yayımlayan Gabriele von Watzdorf, Lindenberg 2000, s. 92 vd.

${ }^{100}$ Karşılaştırma için bkz Heribert Franz Köck: „Rechtliche und politische Aspekte der Europäischen Integration“", Wiener Blätter zur Friedensforschung 2002, s. 1 vd.

101 Bkz Schambeck: Über die Idee einer EU-Verfassung, s. $227 \mathrm{vd.}$ ve Eine Verfassung für Europa, yayımlayanlar: Klaus Beckmann, Jürgen Dieringer, Ulrich Hufeld, Tübingen 2004.

${ }^{102}$ ABI. 2000, No. C 364/1; Europarecht (Avrupa Hukuku), a.g.y. s.235 vd.

103 Heribert Franz Köck : „Der Konventsentwurf - Überblick und Analyse“, yayımlandığı yer: Eine Verfassung für Europa, s. 225 vd. başlıklı makalesinde konuyla ilgili olarak şöyle der: Avrupa Birliğinin bir anayasasının olma ihtimali onun 25 üyeden müteşekkil olacağı ihtimaline kıyasla daha güçlüdür. Anayasa sözleşmesi bağlamında İngiltere'de bir referandumun yapılacağı ve bu 
referandumda Başbakan Blair'in İngiltere'nin AB ile münasebetlerini de oylamaya sunacağ bilgisi bu tür fikirlerin tamamen reddedilemeyeceğine işarettir. (s. 250)

${ }^{104}$ Robert Schuman, Für Europa, Konrad Adenauer'in önsözü ile, Hamburg-GenfParis 1963, s. 47.

105 Avrupa İçin Anayasa Taslağı, 13 Haziran ve 10 Temmuz 2003 tarihlerinde Avrupa Konvansiyonu tarafından uzlaşma sürecinde kabul edilmiştir; kaynak: Europäische Gemeinschaften, s.5.

${ }^{106}$ Avrupa için Anayasa Taslağı, s. 61.

107 Konu için bkz Herbert Schambeck „Die Grundrechte im demokratisichen Verfassungsstaat";, yayımlandı̆̆1 yer: Ordnung im sozialen Wandel, Festschrift für Johannes Messner, yayımlayanlar: Alfred Klose, Herbert Schambeck, Rudolf Weiler ve Valentin Zsifkovits, Berlin 1976, s. 447 vd. Aynı yazar: „Grundrechte in der Lehre der katholischen Kirsche“, yayımlandığ yer: Handbuch der Grundrechte in Deutschland und Europa, yayımlayanlar: Detlef Merten ve Hans-Jürgen Papier, cilt 1, Heidelberg 2004, s.350 vd, özellikle 353 vd.; ayrica aynı yazar: „Gott und das Verfassungsrecht“", L'Osservatore Romano, Alman dilinde haftalık yayın, 16 Ocak 2004, No 3, s. 12; Bir de Karl Korinek „Die Gottesebenbildlichkeit aller Menschen als Grundlage moderner Grundrechtkataloge", yayımlandığı yer: Diplomatie im Dienst der Seelsorge, Festschrift für Donato Squicciarini, yayımlayanlar: Egon Kappelari ve Herbert Schambeck, Graz 2002, s. 76 vd.

${ }^{108}$ Papa Johannes Paul II.; „Die wahren Werte in den Dienst aller stellen - für ein Europa des Menschen, über dem das Angesicht Gottes leuchtet“, L'Osservatore Romano, Alman dilinde haftalik yayın, 2 Nisan 2004, 34. yıl, No. 14, s. 7.

${ }^{109}$ Papa Johannes Paul II, Achtung der grundlegenden Menschenrechte gefordert, L'Osservatore Romano, Alman dilinde haftalık yayın, 26 Mart 2004, No. 13, s. 7.

${ }^{110}$ L'Osservatore Romano, a.g.y.

${ }^{11}$ Aynntılar için Herbert Schambeck, Grundrechte und Sozialordnung, Gedanken zur Europäischen Sozialcharta, Berlin 1969; aynca Fischer/Köck/Karollus, a.g.y. s. $238 \mathrm{vd}$.

112 Bericht des Vorsitzenden an den Präsidenten des Europäischen Rates, Brüksel 18.7.2003, dok. CONV 851/03, s.14.

${ }^{113}$ Say1 44 ve ek IV, Schlussfolgerungendes Europäischen Rates vom 3. und 4. Juni 1999.

${ }^{114}$ ABI. 2000, No. C364/1; Europarecht, s. 235 vd.

115 Ayrıntılar için Köck, Der Konventsentwurf, s. 225 vd., özellikle s. 228 vd. 
${ }^{116}$ Konu için bkz Kirchhof, Europäische Einigung und der Verfassungsstaat der Bundesrepublik Deutschland, s. 63 vd.; ayrica Schambeck, Über die Idee einer EUVerfassung, s.227 vd.

117 Entscheidungen des Bundesverfassungsgerichts der Bundesrepublik Deutschland 89, 155.

118 Bkz Neisser, yayımlandığı yer: Neisser/Verschrägen, a.g.y. s.38 vd., ayrıca Fischer/Köck/Karollus, a.g.y. s. 329 vd.

${ }^{119}$ Ayrıntılar için Fischer/Köck/Karollus, a.g.y. s. 402 vd.

${ }^{120}$ Konu için bkz Fritz Machatschek, „Europa als Ganzes“, yayımlandığı yer: Enzyklopädie der Erdkunde, Leipzig - Viyana 1929, s.1 vd.; Jürgen Fischer, Oriens - Occidens - Europa, Wiesbaden 1957 ve Josef Isensee „Europa - die politische Erfindung eines Erdteils", yayımlandığı yer: Europa als politische Idee und als rechtliche Form, s. 104 vd.

${ }^{121}$ Bkz Erwin Matsch, Der Auswärtige Dienst von Österreich-Ungarn 1720 - 1920 , Viyana 1986; aynca Hans Plattner: Die Türkei - eine Herausforderung für Europa, Münih 1999, s. 168 vd.

122 Bilgi için Samuel P. Huntinton, Kampf der Kulturen, Münih - Viyana 1997, ve OECD Economic Surveys, Turkey 1997.

${ }^{123}$ Başkalarının yanı sıra bkz Hasan Basri Elmas, Turqui - Europe: une relation ambiquë, Paris 1998; ve Türkiye Araştırmaları Merkezi: Die Türkei und Europa, Essen 1998; ve Plattner, a.g.y. s. 177 vd.

124 Avrupa Komisyonu, Üyelik Yolunda Türkiye Hakkında Olağan İlerleme Raporu, Brüksel 2003.

${ }^{125}$ Avrupa Komisyonu, İlerleme Raporu, s. 161.

${ }^{126}$ Avrupa Komisyonu, İlerleme Raporu, s. 151.

${ }^{127}$ Avrupa Komisyonu, İlerleme Raporu, s. 150 vd.

${ }^{128}$ Avrupa Komisyonu, İlerleme Raporu, s. 7.

${ }^{129}$ Konu hak. bilgi için Plattner, a.g.y. s. $145 \mathrm{vd}$.

${ }^{130}$ Bkz Matthias Becher, Karl der Grosse, Münih 1999, s. 69 vd.

131 Konu hak. bilgi için: Kertin Tomenendal, Das türkische Gesicht Wiens, Viyana 2000, s. 63 vd.; aynca Oliver Rathkolb (yayımlayan): 250 Jahre - Von der Orientalischen zur Diplomatischen Akademie in Wien, Festschrift, Viyana 2004.

132 Bkz Josef Nadler: Franz Grillparzer, Vaduz 1948, s.84 vd.; ayrica Franz Grillparzer, Tagebuch auf der Reise nach Constantinopel und Griechenland, Salzburg 1988. 
${ }^{133}$ Bilgi için bkz Peter Gay, Wolfgang Amadeus Mozart, Hildesheim 2001, s. 197 vd.

${ }^{134}$ Aynntılar için: "120 Jahre St. Georg”, Sankt Georgsblatt, 18. y1l, Nisan/Mayıs 2003.

${ }^{135}$ Mesut Y1lmaz: "Festvortrag, Die Türkei in der Europäischen Union: Belastung oder Chance?", yayımlandığı yer: Die Türkei und Europa, yayımlayan: Herbert Batliner-Europainstitut in Salzburg, Salzburg 2003, s. 22 vd.

${ }^{136}$ Y1lmaz, a.g.y., s. 54 vd.

${ }^{137}$ Konu hak. bilgi için bkz: Joseph H. H. Weiler, „Ein christliches Europa”, Erkundigungsgänge, Salzburg-Münih 2004, s. 66 vd.; aynca: Egon Kapellari: „Toleranz ist keine Einbahnstraße”, Academia Mai 2004, s. 9 ve ayn yazar: „Es gibt kein Europa ohne oder gegen die Christen", Kathpress-Tagesdienst Nr. 111, 12.5.2004, s. 2 vd.; aynca: Christph Kardinal Schönborn, Mariazell-Wallfahrt: „Etappe auf dem Weg zum Miteinander in Europa“, Kathpress-Tagesdienst Nr. $114,16.5 .2004, \mathrm{~s} .3 \mathrm{vd}$.

${ }^{138}$ Bkz örneğin: Heinz Kramer, Die Europäische Gemeinschaft und die Türkei, Baden-Baden 1988; Islam in Modern Turkey. Religion, Politics and Literature in A Secular State, yayımlayan: Richard Tapper, Londra 1991; Molly Grene, A Shared World. Christians and Muslims in the Early Modern Mediterranean, Princeton 200; ve Dan Goffmann, The Otoman Empire and Early Modern Europe, Cambridge 2002.

1397 Şubat 1992 tarihli Maastrich Sözleşmesi, ABI. 1992, No. C 191, s. 4 vd., ayrica ABI. 1992, No. C 224, s. 1 vd.

140 Josef Isensee, Son söz: "Der Terror und der Staat, dem das Leben lieb ist", yayımlandı̆̆ı yer; Der Terror, der Stat und das Recht, yayımlayan aynı, Berlin 2004 , s. 83 vd. 